\title{
The Effectiveness Of Batubara's Consumers Disputes Resolution Agency In Consumers Disputes Resolution
}

\author{
Purnama Hidayah Harahap \\ Institut Agama Islam Negeri Padangsidimpuan \\ Jl. H.T. Rizal Nurdin KM. 4,5 Sihitang Padangsidimpuan \\ Email: purnamahidayah.harahap@gmail.com
}

\begin{abstract}
The mismatch between consumers and producers can cause large potential disputes. The disputes can be resolved outside of the court through the Consumers Disputes Settlement Agency in accordance with Law No. 8 of 1999 concerning consumers protections. The qualitative descriptive method used in this study aims to examine the status of human groups, circumstances or conditions that are not manipulated or normal and natural. The purpose of this research is to find out the obstacles of BPSK in implementing UUPK and investigate the necessary coordination procedures. The results of the study found that the obstacles that hamper BPSK's performance in providing consumers rights protection in accordance with their duties and authority are the quality of human resources, human resources competence where almost $50 \%$ of BPSK workers were non-law majors, small funding factors, the lack of assets and knowledge of the community and other institutions about BPSK.
\end{abstract}

Keywords: effectiveness, disputes resolution, BPKS

\begin{abstract}
Abstrak
Ketidakselarasan antara konsumen dan pelaku bisnis dapat menyebabkan potensi sengketa yang sangat besar. Dalam hal ini perselisihan dapat diselesaikan di luar pengadilan yaitu oleh Badan Penyelesaian Sengketa Konsumen menurut UndangUndang Nomor 8 Tahun 1999 tentang Perlindungan Konsumen. Metode deskriptif kualitatif digunakan dalam penelitian ini bertujuan untuk memeriksa status kelompok manusia, keadaan atau kondisi yang tidak dimanipulasi atau normal dan alami. Tujuan penelitian ini untuk mengetahui hambatan BPSK dalam mengimplementasikan UUPK, menyelidiki prosedur koordinasi yang diperlukan. Hasil penelitian ditemukan bahwa kendala yang menjadi penghambat kinerja BPSK dalam memberikan perlindungan hak-hak konsumen sesuai dengan tugas dan wewenangnya adalah kualitas sumber daya manusia, Kompetensi perangkat hampir 50\% staf memiliki pendidikan sarjana non-hukum, faktor pembiayaan atau alokasi anggaran yang kecil dan kurangnya aset. kurangnya pengetahuan masyarakat dan lembaga lain tentang BPSK.
\end{abstract}

\section{Kata kunci: Efektivitas, Penyelesaian Sengketa, BPSK}




\section{The Effectiveness Of Batubara's Consumers Disputes Resolution \\ Agency In Consumers Disputes Resolution}

Purnama Hidayah Harahap

\section{INTRODUCTION}

Economic progress is an important parameter for assessing the economic performance of a country. One of the main factors causing the development of a country's economy is the economic activities carried out by business actors. These activities can consist of transactions of goods or services carried out by several parties such as business operators and consumers. Consumers are defined as individual users of products and services in society, both for personal and group needs and other living creatures and not for sale (Zulham, 2013). As for things that affect consumers before buying are all the physical and psychological processes and activities that occur when the consumers buy, use, or spend products and services after their own analysis.

The general public is usually more familiar with business actors as producers. Manufacturers are also often similarized with entrepreneurs. Some people think that producers are also product creators and entrepreneurs. In Article 1 paragraph 3 of UUPK Number 8 of 1999, producers are business actors or business entities, both in the form of legal or non-legal entities established and located within the jurisdiction of the Republic of Indonesia, both private and corporate through agreements, to conduct business activities in various fields of economics.

UUPK Article 1 Paragraph 11 formulates that BPSK is a forum that functions to handle and resolve cases between the producers and consumers (Zulham, 2013). BPSK has a simple nature and small scale. BPSK was established on the legal basis stated in UUPK Article 49 paragraph 1. BPSK must exist in every city and regency as contained in the Ministry of Industry and Trade No.350 / MPP / Kep / 12/2001. The cost of applying the BPSK roles is borne by the State Expenditure Budget and the Regional Expenditure Budget in accordance with the Presidential Decree Number 9 of 2001 Article 90. In the Presidential Decree, BPSK's jurisdiction regional restrictions are not regulated to facilitate consumers in reaching BPSK. With that, consumers can submit their cases to BPSK according to their wishes.

Entrepreneurs and consumers have the same goal that is looking for profits in making transactions. Business actors compete with each other to attract consumers' interest by showing various productivity into a form of goods or services that have a selling value. This is different from consumers who only buy 
to fulfill their every need in obtaining satisfaction with certain products from business actors.

The position of the business actors as producers in relation to consumers as users in such circumstances becomes disproportionate, in which users or customers tend to be targeted by the business activities of the entrepreneurs who try to get the maximum profit through advertising, promotion, marketing techniques, and other ways which harms other parties such as the implementation of standard agreements. The law No. 8/1999, which is then abbreviated as UUPK, regulates the protection of consumers in two methods: handling cases outside the court and handling cases in the court. Handling cases outside the court means handling the cases peacefully by parties involved through BPSK.

This research will examine how BPSK works effectively and efficiently in the resolutions of consumers' cases. In its application, there had been a number of consumer disputes that should have been resolved by BPSK but did not proceed as they should.

\section{LITERATURE REVIEW}

Consumers disputes are interpreted in accordance with the decree of the Minister of Industry and Trade numbered 350 / MPP / Kep / 12/2001 regarding the implementation of the duties and authorities of BPSK Article 1 number 8 as a case with the user who is required to replace any damage, pollution and use of the product or service. The UUPK alone does not provide a description of how consumers' cases as users are understood. According to UUPK there are keywords such as (Suherman, 2004): (a) "Consumers are every individual user of products and services available in the community, both for personal and group needs or for other living things on the grounds that they are not traded". (b) Furthermore, "business actors are all individuals or business entities, whether in the form of legal entities or not that are formed, domiciled and carry out their agenda in the jurisdiction of Indonesia, either private or corporate in accordance with the agreements in conducting business in various types of economic products or services". The matter becomes a barrier between the users and the producers according to Article 1 of the UUPK."Consumer disputes" are issues emerge between business people and users. Producers are explained as individuals as 


\section{The Effectiveness Of Batubara's Consumers Disputes Resolution Agency In Consumers Disputes Resolution}

Purnama Hidayah Harahap

well as legal and/or business entities. This is contained in Article 1 number 11 UUPK.

There are many steps that can be taken by those who are in conflict with the third party assistance. Literally, the case handling effort can be understood as a form of matters carried out by those who are in conflict to meet with the intention of resolving the problem. The case handling can be done through litigation (in court) or non-litigation (outside court) legally.

In UUPK, the handling of problems between consumers is regulated and divided into 2 forms, namely (Rusli, 2012): (a) The peaceful handling of cases by the parties involved without the involvement of BPSK (non-litigation); (b) The handling of cases through BPSK by means of conciliaton, mediation, arbitration or a judicial institution (litigation).

The duties of BPSK and its authorities are contained in the article 52 of the UUPK, as follows: (a) Taking actions and completing consumers cases through mediation, arbitration, and consolidation; (b) Providing consultation regarding consumer protection; (c) Filling out the standard clause; (d) Providing a report to the general investigator in case of non-compliance with regulations; (e) Processing verbal or written complaints from consumers; (f) Conducting research and examination of consumers cases; (g) Calling the violators; (h) Presenting all witnesses and individuals who are considered to have knowledge of the violations for questioning; (i) Asking the investigators for help to bring the party mentioned in the previous point if they refuse to fulfill the summons; (j) Obtaining, examining and giving value to letters, documents and other evidence in the investigations and examinations; (k) Giving decisions and determining the loss of consumers; (l) Notifying the decisions to the violators of the rules; (m) Giving administrative penalties to the violators of the rules.

Under the article 23 of the UUPK, if the violators do not receive, respond and fulfill demands to compensate the consumers, the consumers are given the rights to sue the businessmen by sending a lawsuit to the court at the consumers' domiciles. 


\section{Effective Parameters in Consumers Disputes Resolutions}

In the administration encyclopedia, an effectiveness is a condition of the operation of a desired cause and effect. If a person conducts a behavior with a specific purpose, then he is considered effective if the behavior results in something in accordance with his wishes. "

According to SoerjonoSoekanto, the effectiveness of a regulation is determined by five elements (Soekanto, 2008): (a) The rules themselves; (b) The elements of the legal apparatus, namely those who make or implement regulations; (c) The elements of means and facilities that encourage the enforcement of the law; (d) The elements of community in the applied jurisdiction.

When linked to BPSK's effectiveness analysis as a forum that resolves consumers' cases, an institution can be considered effective if: (a) Having good regulatory instruments; systematic, synchronous with the applicable system; (b) Having adequate and well-maintained facilities and infrastructure, having competent human resources; (c) Having provisions that can be respected and implemented well; Getting supports from citizens who are aware of their rights and obligations as consumers.

\section{RESEARCH METHODS}

This research is the result of field studies. The analysis is descriptive qualitative by using two data sources, primary data and secondary data. Data collection techniques are interviews, observation and documentation, while data analysis techniques are done through qualitative processing and analysis that emphasizes deductive and inductive conclusions.After the analysis process, the data is explained inductively.

\section{RESEARCH RESULTS}

The Constraints Faced by BPSK Batubara in Consumers Disputes Resolutions. There are many obstacles faced by BPSK Batubara, including:

a) The number of cases; Since its establishment in 2010, BPSK has become a place to complain for people whose rights are denied by business actors when they become consumers of their goods or services. According to BPSK consultant, Khairil Anwar, there were 600 cases of consumer complaints during 2015. Of the 600 cases, 200 of them have been decided and are in the 


\section{The Effectiveness Of Batubara's Consumers Disputes Resolution Agency In Consumers Disputes Resolution}

Purnama Hidayah Harahap

process of being appealed in several courts in Kisaran, Simalungun, TebingTinggi, and others. 100 of them are in inkrach and are in the process of execution while 12 cases are in the process of cassation in the Supreme Court, while others are still in the stage of examining witnesses and evidence. The large number of cases admitted has resulted in many unsolved cases, one of which is the expiry case being sued by a resident of Air Putih, Batubara (Padli, personal communication, August 19th, 2019).

Besides that, BPSK also handles cases outside its authority, including: (a) The case of a member of the Labusel community, North Sumatra, Safinah, who sued BRI. Safinah assessed BRI's move to auction off land collateral as a wrong move. Even the local BPSK also sentenced forced money to BRI. Upon the BPKS decision, the Supreme Court annulled it. The Supreme Court stated BPSK was not authorized to adjudicate credit disputes with guaranteed mortgage rights. (b) LabuhanBatu resident, Dermansyah Pane, also sued PT. Summit Oto Finance went to BPSK because Summit Oto pulled the motorcycle from Pane's hands because he was late in paying credit. BPSK granted Pane's claim and sentenced Oto to return the motorcycle to Pane. BPSK even sentenced Oto to pay a fine of Rp 100,000 per day if they did not return the motorcycle to Pane. The Supreme Court annulled the verdict. The cassation council consisting of SyamsulMaarif, Abdurrahman, and I GustiAgungSumantaha assessed that Pane's actions not to pay motorcycle installments every month were ordinary civil disputes, not consumers disputes. (c) Padangsidimpuan City District Court overturned the decision issued by BPSK Batubara No.390 / PTS / Arbitration / BPSK-BB / IX / 2015 dated February 1, 2016 because the decision was judged to be legally flawed. Based on the decision No.06 / Pdt.Sus / 2016 / PN Psp signed by BallamanSiregar dated May 8, 2016, by law the defendant (LiaOktaria) has been wrong in filing a lawsuit through BPSK Batubara Regency because it does not have the authority to prosecute.

In accordance with the Consumer Protection Act, BPSK's authority is limited and only limited to adjudicating cases of consumers-producers that are against regulations, namely: damage, pollution or loss due to consuming goods / services, Advertising is different from goods, The label is different from the item, Goods expired. 
The Supreme Court also provides clear signs regarding the lawsuit material. The followings are not allowed in consumer matters: Claiming immaterial losses, Demanding forced money, Sueing for confiscation. If the consumers-producers conflicts occur because of a violation of an agreement, the case that arises should be resolved in a general court, not in BPSK.

b. Receiving Cases from Outside of its Jurisdiction Region

BPSK can carry out cases handlings in accordance with what is stated in the Consumer Protection Act and the decision of the Minister of Industry and Trade numbered 350 / MPP / Kep / 12/2001. In this regard, BPSK Batubara should operate in its jurusdiction area but apparently it handled cases outside of its authority to other provinces as well such as Jambi, PekanBaru, Padang, etc (Adi Putra, personal communication, August 14th, 2019).

c. HR issues in BPSK

Different cultural backgrounds in each part of BPSK Batubara creates differences of opinion among members. Moreover, almost $50 \%$ of members do not have a Bachelor of Law background so most of them still need trainings and comparative studies in handling cases from other branches of BPSK whose performance is better in order to provide increased knowledge or experience in better handling consumers' cases at BPSK.

d. Problems with BPSK Batubara operational support facilities

The central or regional government is not maximizing the function of BPSK Batubara. This can be seen from the minimal facilities or operational budget assistance for BPSK Batubara. Budgets in several cities prepared from the district and city APBD are far from a reasonable standard until the operationalization of BPSK is shuffling. Not only that, even after being official for 2 years (2013-2014), the disbursement of APBD funds for the operationalization of BPSK did not exist at all even though the proposal for the BPSK budget had been carried out starting in 2013 and 2014. BPSK Batubarahas yet to have its own office (Husni, personal communication, August 16th, 2019).

e. The absence of a code of ethics at BPSK Batubara

As an institution that carries out the role of the court, each individual in BPSK is required to be able to carry out his professional responsibilities. 


\section{The Effectiveness Of Batubara's Consumers Disputes Resolution Agency In Consumers Disputes Resolution}

Purnama Hidayah Harahap

Professional actors must have "rules of thumb" or code of ethics to keep them in the corridors of professional ethics.

f. Incomplete and confusing and limited regulations.

Weaknesses in the legislation governing BPSK can be cited as the first factor causing obstacles to the operationalization of BPSK Batubara. Discussions on various obstacles faced also directly address various weaknesses of the UUPK (Law No. 8 of 1999) and its implementing regulations.

g. Operational obstacles as a form of system integration in Indonesia are already rooted in the Civil Law system.

Viewed from a sociological juridical perspective, BPSK Batubara is faced with a variety of significant obstacles in carrying out its duties and functions. BPSK Batubara is an imperfect combination of common law and civil law. That said, BPSK Batubara is built from the idea of the Small Claim Court (SCC) that developed in countries based on common law systems that position the non-litigation process the same as the litigation process. Because Indonesia is already rooted in the civil law system, the BPSK Batubara becomes a settlement institution outside of the court whose decisions are dependent on the court (in terms of executions and objections).

h. BPSK Batubara was dismissed in accordance with the Decree of the Minister of Industry and Trade numbered 679 / M-DAG / Kep / 5/2017.

All assemblies of BPSK Batubara are honorably dismissed. In the discussions of the SNKI Consumer Protection Working Group (National Inclusive Financial Strategy) it was decided that starting from May 5, 2017, the BPSK Batubara permit was revoked. This decision was made based on warnings from the Department of Commerce (OJK). If there are still calls or processes from BPSK Coal after May 5, 2017, these calls can be ignored until a new management is formed. OJK and the Ministry of Trade work together to improve the quality of BPSK. This is similar to the existence of LAPS in the Financial Services Sector to handle cases outside the court which are overseen by the OJK.

Another reason for the dismissal of BPSK Batubara is that BPSK Batubara handles cases outside of its jurisdiction even though the working area is only limited to the scope of the district. BPSK can only carry out cases 
handlings in accordance with its working area so that it is considered a violation of the Consumer Protection Act and the Decree of the Minister of Industry and Trade numbered 350 / MPP / Kep / 12/2001. The above laws require consumers agreements with financial service institutions to settle disputes beyond what was agreed at the beginning of the agreement or the form of financial product utilization. OJK studied the cancellation of BPSK and the Supreme Court's decisions and found that there was no prior agreement. The cancellation of the improper nature of BPSK operates to the detriment of consumers and LJK because the disputes are not resolved while they suffer financial loss. Based on OJK data, disputes handled by BPSK throughout Indonesia (32 Regencies / Cities) as of August 2016 totaled 493 cases. Around 48 percent of them (235 cases) were handled by BPSK Batubara (AntoPrabowo, personal communication, May 31st, 2017). This is a problem because it turns out some of the problems come from outside of the Regency of Batubara.

\section{How BPSK Batubara Overcomes the Obstacles It Faced in Resolving Consumers Disputes}

In carrying out its duties and functions as consumers disputes resolution board in accordance with its authority, BPSK Batubara always refers to the Law No. 8 of 1999 concerning consumers protections and other laws in accordance with the consumers disputes encountered. Thus, the barriers faced by BPSK Batubara in dealing with consumers disputes are addressed by: (a) Compiling technical instructions and implementations of consumers disputes resolutions signed by the Chairman of BPSK in the regency of Batubara; (b) Submitting a budget request through the Batubara Regency APBD in the 2013 to 2016 fiscal year and was realized in 2015 with a funding of Rp. 150,000,000. (c) Forming a code of ethics drafting team. (d) Holding socialization processes through seminars, LK-PPM and the likes. (e) Cooperating with the local government of Batubara Regency and the Police to conduct surveillance of markets and to become expert witnesses related to the consumers cases.

\section{Building on the Concept of Effective Consumers Disputes Resolution Institutions}




\section{The Effectiveness Of Batubara's Consumers Disputes Resolution Agency In Consumers Disputes Resolution}

Purnama Hidayah Harahap

The concept of an ideal consumer dispute resolution agency will be built based on a study of the effectiveness of BPSK. The assumption is that the consumer dispute resolution agency will be effective if the following indicators are met properly: (a) Adequate Legal Rule Aspects are an effective requirement for an institution in carrying out its main tasks and functions. The rules are also the basis for the legality of every action taken by the institution. Therefore, the more detailed and synchronized the rules, the higher the accuracy of the institution's actions. (b) Standard Facilities and Infrastructure Aspects, The support for adequate facilities and infrastructure is one of the absolute requirements for an institution to be able to operate optimally. At present, BPSK's facilities and infrastructure are still inadequate. Many BPSKs do not have their own buildings and ride buildings with other agencies. (c) Human Resources Aspect. Human resources are the most substantial capital in supporting the effective performance of an institution because human resources are the organs that drive all the activities. Therefore, the better the quality of the human resources of the institution, the better the performance will be, as is the case for BPSK. (d) Government policy, Government support is an absolute must to be fulfilled in order for BPSK to carry out the duties and authorities effectively and independently.

The support of government policies are as follows: (a) The existence of government policies related to the allocation of clear and sufficient budgeting. This will certainly improve the quality of BPSK's facilities and infrastructure and the quality of its human resources; (b) The existence of a policy regarding technical guidance for BPSK members on a regular basis from inauguration to retirement. The trainings can trainings in negotiation techniques, mediation, etc., (c) The existence of an internal synergy policy between the Ministry of Trade and the Judicial Institution related to the enforcement of consumer protection regulations through BPSK.

\section{CONCLUSIONS}

The conclusions obtained from the results of this study are: (a) Based on the achievement of objectives, BPSK Batubara is still in the "ineffective" category because of the obstacles and problems in the implementation of the agency's activities. (b) There are factors that influence the achievement of goals and 
effectiveness of BPSK Batubara, namely: the ability to adjust, work productivity, job satisfactions and HR utilization. All of these factors must be in line and be sustainable. However, this cannot be separated from the roles and supports of BPSK Batubara members and the central and district governments.

Based on the results of this study, the researcher provides the following suggestions: (a) BPSK Batubara should improve its internal conditions and infrastructure so that job satisfaction is guaranteed and the staffs can work optimally in the interest of consumers protection. BPSK should also increase socialization so that this agency is better known and understood to the public. (b) The leadership board members of BPSK Batubara, in this case the central and district governments, should pay special attention to BPSK Batubara, given that its roles in helping the district court resolving cases of consumers disputes with business actors is very heavy. They should also give attention to the welfare of their employees so that they can work optimally. The Batubara Regency Government should provide sufficient budget for this because one of the factors in the obstruction of the implementation of tasks is related to the budget. (c) BPSK should provide training in accordance with their area of work and set operational standards for BPSK Batubara so that all staff have the same understanding in running the agency.

The implications of the findings of this study are: (1) Theoretical implications;

(a) Understanding the reasons for the inability of BPSK Batubara to carry out its duties and authority to resolve consumers disputes, (b) Knowing the obstacles in implementing UUPK in BPSK Batubara, (c) Knowing the coordination process with BPSK in realizing legal protection for consumers. (2) Practical Implications The results of this study are used as input for BPSK Batubara and the government in realizing the visions and missions in accordance with applicable laws and regulations in order to achieve the effectiveness of the agency in the resolution of consumers disputes. 


\section{The Effectiveness Of Batubara's Consumers Disputes Resolution \\ Agency In Consumers Disputes Resolution}

Purnama Hidayah Harahap

\section{REFERENCES}

\section{Book}

Hartono, Sunaryi. (1994). Penelitian Hukum Indonesia Pada Akhir Abad ke-2o. Bandung: Alumni.

Romli, Atmasasmita. Reformasi Hukum. Hak Asasi Manusia \& Penegakan Hukum. Bandung: Mandar Maju. 2001.

Suherman, Ade Maman. (2004). Arbitrase dan Alternatif Penyelesaian Sengketa. Aspek Hukum dalam Ekonomi Global. Jakarta: Ghalia Indonesia. Anggota IKAPI Indonesia.

Soekanto, Soerjono. (2008). Faktor-Faktor yang Mempengaruhi Penegakan Hukum. Jakarta: PT. Raja Grafindo Persada.

Susanti, Adi Nugroho. Proses Penyelesaian Sengketa Konsumen Ditinjau dari Hukum Acara Serta Kendala Implementasinya. Jakarta: Kencana Prenada Media Group. 2008.

Sunaryati, Hartono. Penelitian Hukum Indonesia PadaAkhir Abad ke-2o. Bandung: Alumni. 1994.

Soerjono, Soekanto. Faktor-Faktor yang Mempengaruhi Penegakan Hukum. Jakarta: PT. Raja Grafindo Persada. 2008.

Soerjono, Soekanto. Efektivitas Hukum dan Penerapan Sanksi. Bandung: CV. Ramadja Karya. 1988.

Yusuf, Shofie dan Somi Awan. Sosok Peradilan Konsumen. Lembaga Konsumen. Jakarta: The Asia Foundation. 2004.

Zulham. Hukum Perlindungan Konsumen. Jakarta: Prenadamedia Group .2013

\section{Journal}

Aswandi, Dedi., Marilang dan Nurjannah. Efektivitas Badan Penyelesaian Sengketa Konsumen (BPSK) Dalam Penyelesaian Sengketa Konsumen. Alauddin law development Journal, Universitas Islam NegeriAlauddin Makassar.Vol. 1 No. 3. 2019.

Hasani, Untan. Efektivitas Badan Penyelesaian Sengketa Konsumen (Bpsk) Sebagai Lembaga Alternatif Penyelesaian Sengketa Dalam Rangka Menwujudkan Perlindungan Hukum Bagi Konsumen (Studi Bpsk Kota Pontianak) Jurnal Nestor Magister Hukum, UniversitasTanjungpura vol.3 No.3. 2016. 
Tami Rusli. Penyelesaian Sengketa Antara Konsumen Dan Pelaku Usaha Menurut Peraturan Perundang-Undangan. Jurnal Keadilan Progresif Volume 3 Nomor 1 MAret 2012.

Hidayat, Farid.Efektivitas Badan Penyelesaian Sengketa Konsumen Di DIY Sebagai Alternative Dispute Resolution (ADR) Dalam Industri Keuangan. FEBI UIN Sunan Kalijaga. Jurnal Kertha Semaya, Vol. 8 No. 4 Tahun 2020.

Hadiati, Mia dan Mariske Myeke Tampi. Efektivitas Mediasi dalam Penyelesaian Sengketa Konsumen oleh Badan Penyelesaian Sengketa Konsumen (BPSK) di DKI Jakarta. Jurnal Hukum PRIORIS. Vol. 6. No. 1. 2017.

\section{Interview}

Putra, A. (2019, August 14). Personal interview.

Husni. (2019, August 16). Personal interview.

Padli. (2019, August 19). Personal interview.

Prabowo, A. (2017, May 31). Personal interview. 